\title{
Online Shopping Sales Promo and its Perception Among Undergraduate Students in Osogbo, South Western Nigeria
}

\author{
Kamoru Aremu Salaudeen \\ Fountain University, Osogbo, Nigeria - kamoru.salaudeen@gmail.com \\ Mariam Ayankemi Omotosho \\ Fountain University, Osogbo
}

\begin{abstract}
This paper explores the perception of university undergraduates about online shopping sales promo. The researchers adopted a qualitative approach, conducting four sessions of focus group discussion (FGD) among forty students selected through purposive and snowball sampling techniques across the two colleges of the university that served as the study setting: College of Management and Social Sciences and College of Natural and Applied Sciences. The study is underpinned by the consumer perception theory which explains consumer

behaviour by analyzing motivations for their buying decisions and preferences. Major findings revealed that university undergraduates in this study trust online sales promo and were active in benefiting from it while being influenced by certain factors that shaped their perception of online sales platforms and promotions. It is therefore recommended that online shops and malls need to provide more convenience, competitive price, product variety, after sales services in order to attract more patronage to for their products.
\end{abstract}

Keywords: Online stores, online sales promo, mediatization, preference, students

\section{Promoção de Compras Online e a sua Percepção entre Estudantes Universitários em Osogbo, Sudoeste da Nigéria}

\section{Resumo}

Este artigo explora a perceção dos estudantes universitários sobre a promoção de compras online. Os investigadores adotaram uma abordagem qualitativa, conduzindo quatro sessões de discussão em grupo de foco (DGF) entre quarenta estudantes selecionados através de técnicas de amostragem propositada e de bola de neve nas duas faculdades da universidade que serviram de cenário para o estudo: Faculdade de Gestão e Ciências Sociais e Faculdade de Ciências Naturais e Aplicadas. O estudo é sustentado pela teoria da perceção do consumidor que explica o comportamento do consumidor através da análise das 
Online Shopping Sales Promo and its Perception Among

Undergraduate Students in Osogbo, South Western Nigeria

motivações para as suas decisões de compra e preferências. Os principais resultados revelaram que os estudantes universitários deste estudo confiam na promoção de vendas online e foram ativos em beneficiar dela, ao mesmo tempo que foram influenciados por certos fatores que moldaram a sua perceção das plataformas e promoções de vendas online. Recomenda-se, portanto, que as lojas e os centros comerciais online ofereçam mais comodidade, preço competitivo, variedade de produtos, serviços pós-venda, de forma a atrair mais clientela para os seus produtos.

Palavras-chave: Lojas online, promoção de vendas online, mediatização, preferência, estudantes.

\section{INTRODUCTION}

Online shopping is almost synonymous to convenient shopping. It is, in fact, a popular means of shopping among the digital natives and migrants. Nowadays, online shopping is fast becoming the norm and gradually replacing the conventional market place among consumers, especially the youth because of its many advantages. Some of the merits of online shopping include low and transparent price, comprehensive assortment of goods and services and a much more convenient shopping alternative that has eliminated such traditional shopping inconveniences like squeezing through crowds, getting stuck in long queue to pay for the goods bought, etc.

Online shopping has become a suitable way to purchase all forms of commodities, whether domestic or office use, even from the remotest part of the world. There are hundreds of websites and applications being created and deployed regularly to cater for the rising demand of comfortable shopping trends. Just like the conventional marketing process, promotion, which is the forth " $\mathrm{P}$ " of the marketing mix is inevitable. Apart from other promotional mix, sales promotion is a prominent marketing communication tool adopted to engineer impulse purchases online (Jiang \& $\mathrm{Ma}$ 2018). Online marketers adopt sales promotional strategies such as coupons, rebates, add-on products and price discounts to boost sales. Other forms of sales promotion such as sweepstakes as well as premiums add excitement and value to brands to encourage brand loyalty. Despite the foregoing, online shopping still suffers prob- 
lems of credibility, reliability, value exchange assurance and impulse purchase leading to post purchase regret (Kempa, Vebrian, \& Bendjeroua, 2020). Among other studies, Tarigan, Sabrina \& Syahputri (2020, p. 143) found that lifestyle which is a function of "activities, interests, and opinions that are reflected in daily activities" has significant positive influence on online purchase decisions. This study which examines how influence of immobile lifestyle during COVID-19 increased online purchase of culinary is similar to the current study in the sense that undergraduate are also usually "trapped" by academic activities on campus, a lifestyle that may influence online purchase for convenience.

This study, therefore, explores the perception of students in a private university in southwestern Nigeria about online shopping sales promo. A qualitative research approach was adopted conducting four sessions of focus group discussion (FGD) among forty students selected through purposive and snowball sampling techniques across the two colleges of the university that served as the study setting: College of Management and Social Sciences and College of Natural and Applied Sciences. In this two-level sampling technique, purposive sampling was first employed to identify few students who had once made online purchase while snowball sampling was then adopted to discover more online buyers among the study population through their friends/school mates.

The main purpose of the study was to find out the perception of undergraduates of a private university in southwestern Nigeria towards online sales promotion and how these sales promotion techniques have influenced their buying behaviour. The following research questions were constructed to drive the study: How do Fountain University students perceive online sales promo? What is the influence of online shopping sales promo on Fountain University students' online buying behaviour? What are the reasons Fountain University students prefer the patronage of certain online shops to others? Underpinned by Consumer Perception Theory, the study reviewed literature on online shopping promotion, its objective and perception among consumers. Thematic constructs like pricing and negotiation, preferences and perception were created to connect literature with the data and findings of the study. 
Online Shopping Sales Promo and its Perception Among

Undergraduate Students in Osogbo, South Western Nigeria

\section{LITERATURE REVIEW}

\section{Online Shopping Sales Promo}

The advent of the internet and online media leading to media convergence has rapidly facilitated a paradigm shift in the sender-audience interface in all forms of communication. This is as a result of the permeating power of the online media narrowing both geographical and social spaces among various players in the communication process by facilitating border penetrations across the globe. This permeating power resulting from mediatization of the modern life and the interactivity feature of the online media has become huge opportunity for media users especially in marketing communication, communication campaigns and fans/public mobilization (Schrøder, 2009; Busse, 2009). In today's marketing environment, online shops and malls- big or small- are gradually taking over the process. This is not only because they exist online, but they also deploy online media for promotional strategies which include online sales promotion more than the traditional physical shops. This situation as captured by Busse (2009), puts both the producer and the consumer as fans at the centre of the interactive marketing exchange process, making buying and selling easier through mediatization of marketing process and sales promotion.

Sales promotions are regarded as short term incentives through add-on products or price reduction that facilitate increase in sales within a period of time. Besides, online sales promotional activities which include coupons, discount, rebates, product sampling, contests, sweepstakes, and premium has grown importance and has worked as a marketing kit for online shopping (Strauss \& Frost, 2012). The promotional activities stimulate the customer to rethink and evaluate the brand (Chang, 2017; Gao, 2015). So, sales promotion has grown as an important tool for the online marketers to understand the customers' preferences, boost the brand image and sales of the business.

Online marketers use sales promotions such as coupons, sweepstakes, premiums, rebates and price discounts not only to increase sales but also to add excitement and value to brands and encourage brand loyalty. Online purchasing of goods, both luxury and basic needs, is prevalent to a much larger extent in recent years due to convenience, speedy transactions, time saving and attractive sales promotional offers. Despite these positive factors, there are various transactional and non-transactional challenges involved such as the consumers being uncomfortable while giving their personal information and sometimes credit card number and so on which act as deterrents (Chang, 2017). 
Online shopping has experienced an explosive growth due to the fact that it represents a more economic and convenient approach to purchasing products. There are a number of reasons people purchase online; for example, consumers can buy anything at anytime and can compare prices from different online stores or websites simultaneously (Nebojsa, Milorad, \& Tanks, 2019).

Chang (2017) says various online shops keep opening leading to a lot of competitions. So the only way to get the consumers attention with customer loyalty is by using sales promo. It is expected that the attractiveness of an online product will bring more customers through the various promotional techniques but then, an unattractive award is badly evaluated when it has no connection with the product or offer. Some online marketers do not employ the use of appropriate sales promotional tools to enhance the achievement of attracting more customers. More promos carried out are usually badly organized and implemented which leads to the aim being defeated thereby having a direct effect on sales volume and profit.

Sales promotion plays an important role in the consumer decision making process (Daniel \& Mambu Bayoh, 2017, as cited in Amankwah \& Asare, 2019; Jiang \& Ma, 2018). Online sales promotion has many advantages compared to traditional sales promotion. It can push right promotion information to right people, break through the limitation of time and space, and spread around the world. One successful case of online sales promotion is Alibaba's annual global online shopping carnival also known as Double 11 day or Single's day held every November 11. On Single's day, this shopping carnival brought the entire Chinese electronic commerce industry an astonishing record volume of transactions worth 91.2 billion RMB in 2015 and 120.7 billion RMB in 2016 (Jiang \& Ma, 2018).

Globally, online shopping constitutes about 2.29 trillion-dollar market (John, 2018) and expected to reach 4 trillion dollars by 2020 (eMarketer, 2016) due to the doubledigit worldwide growth in sales (15\%) and order (13\%) (eMarketer, 2018) in all sorts of online shopping such as business-business, business-consumer (Zuroni \& Goh, 2012). Consumer attitudes toward online shopping usually been determined by two factors; one is trust, and another is perceived benefits (Hoque, Ali, \& Mahfuz, 2015). Therefore, trust and perceived benefits seem to be the critical conjectures of consumer behaviour toward online shopping (Al-Debei, Akroush, \& Ashouri, 2015; Hajli, 2014). Moreover, information quality, merchandise attribute, transaction capability, payment, security/ privacy, delivery, self-consciousness, the consumer's time sense and customer service are strongly predictive of online shopping satisfaction (Katawetawaraks \& Wang, 2011; 
Mudambi \& Schuff, 2010; Liu, He, Gao, \& Xie, 2008; Shergil \& Chen, 2005; Sorce, Perotti, \& Widrick, 2005; Novak, Hoffman, \& Yung, 2000).

Previous studies reported that promotional offers have a significant influence on consumer's purchase decision (Daniel \& Mambu Bayoh, 2017, as cited in Amankwah \& Asare, 2019; Andreti, Zhafira, Akmal, \& Kumar, 2013). A study carried out by Folorunso, Awe, Sharma, \& Zhang (2006) shows that $70 \%$ of the respondents had heard about e-commerce but only $32 \%$ had used it. Similar results from Adeyeye (2008, p. 5 ) shows that only " $16 \%$ of the total respondents sampled shopped online". However, Philips Consulting Ltd. (2016) states that many Nigerians are yet to embrace the culture of online shopping adding that majority of the respondents sampled (62\%) still preferred to shop through traditional retail channels.

The overall objective of online sales promotion is the building of brand loyalty or creating product awareness. Broadly, sales promotion is separated into two categories: consumer sales promotion and trade sales promotion. Customer sales promotion activities are marketing techniques adopted with the focus on end consumers whereas trade sales promotion activities are targeted at dealers, distributors and agents. This tool is used to attract customers or patronize the specific shops or retails to introduce new products or existing products. It is usually done with a view to drawing the attention of customers to retail stores. This is illustrated in figure 1 below:

\section{Figure 1}

Tools of consumer-oriented sales promotion

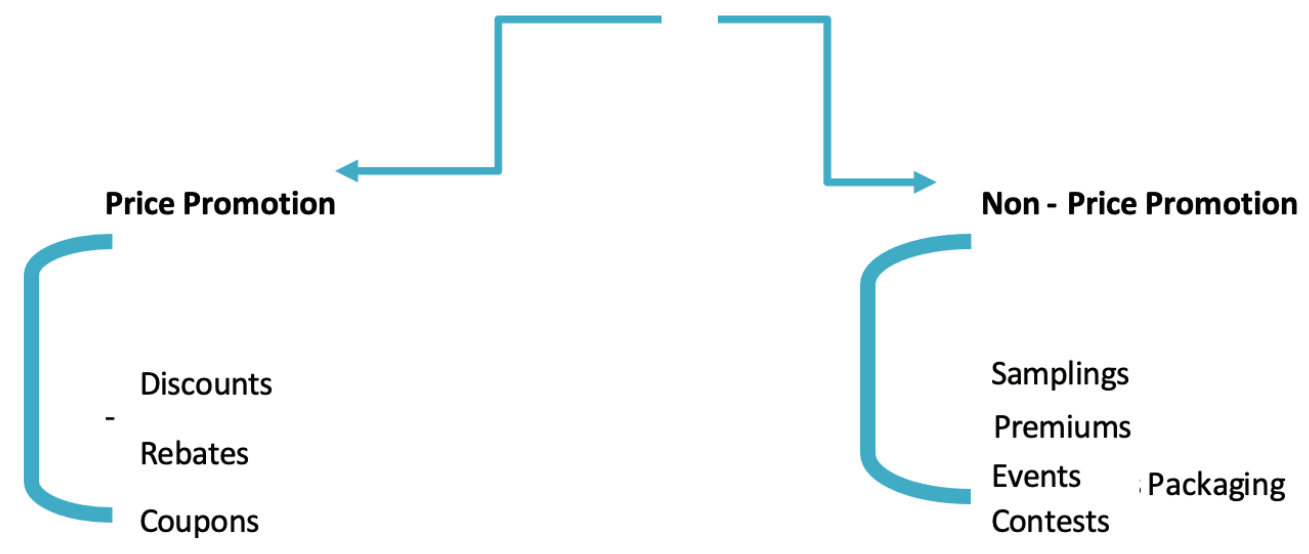

Source: Anuraj Nakarmi(2018) Effect of Sales Promotion on Consumer Behavior. 
Even though sales promotional techniques come in different form, the simplest most common technique is discount offers on the products. The important aspects that is to be considered while using this technique are that it must be sure that the discount is attractive to the customers; it must always consider the bottom line; and to avoid doing it too often for people to consider it as the norm. Secondly, the coupons which are also the frequent sales promotion techniques as discounts commonly used to motivate the customers to purchase. It is a certificate that avail customers a saving on the purchase of a particular product and this certificate is distributed either online or in printed form (Kotler \& Keller, 2014). But there is a very low significant relationship between coupons and consumer buying. This is because coupons sometimes allow the buyer to make a purchase the product which he does not desire to (Shamout, 2016). The coupons would push the customers to buy the product when they think that the price is high or can be incentive to buy the product above the competitors. Thirdly, sampling is the way of introducing the new product to the customers by providing the products for free. The potential customers are targeted in this method and not only introduce the product in the market but also create awareness of the product. There is also the refund and rebates which are not too popular in all the countries but the country like United States it is much popular. In the marketing tactics like refund the customers get excited with the portion of refund that they can have on purchase with the parking tickets or the feedback they provide online about the store. These types of promotional activities are done to grab the attention of the customers. The contests and sweepstakes are simple as winning the gifts that attracts and motivates the customers to go for the product. It is mostly useful for gathering the information of the customers and create the awareness about the new product or the new location for the getting the products Also, the price off deals promotional techniques are the reduction in the price of the promoted products and the customer saves money on purchase. The price reduction may be used for taking the attention of the customers away from the competitors. The customers are always in search of quality products in lower price so the promotional activity of price off deals would increase in sales.

There is also financing where product that requires high resource (money) would be promoted if the seller would itself provide the facility of financing options to the customers. This method of promotion popular in varieties of products such as automobiles, household equipment, and electronic products that is high in price. 


\section{Online Shopping Sales Promo and its Perception Among Undergraduate Students in Osogbo, South Western Nigeria}

Gifting is another promotional technique and the great idea of this promotion is that everyone loves free product and even better when it is given as gift. The gift to the customers gives the chance to test out the products by the customers and make the customer aware about the product meanwhile. Customer would appreciate for such action and would increase the sale of the product. The customers would be excited about the assured gift with the purchase of products that would increase the sales with the excitement of getting something for free. Another is the bonus pack which is getting additional quantity of the same product offered for the standard pack size purchased. The customers purchasing huge quantity than the regular size would be offered the bonus pack. This promotional activity would be used as the strategy for high sales and induce the customers to buy more quantity.

Lastly, the free trail is also the sales promotional method that introduce to the new product in the market to the customers where they get to know about the product before purchasing it. Free trail strategy much more popular for sales of software, computer programs, apps. These are the products that can be used for free for time being and required to be purchased later for further use. This would convince the customers to purchase the for future use.

Sales promotion has a temporary effect on consumer buying behaviour. Many researchers are arguing that sales promotion does not have a long term effect on consumer buying behaviour and also it reduces the revenue, as in coupon, refunds and rebates. These tools are increasing costs (Clow \& Baack, 2007). In this particular point there is an argument; hence other researchers are stating that sales promotion does not reduce revenues because sales promotion can attract and encourage consumer to purchase the product in a higher quantity in lower prices. Moreover, it is stated that the value of product can be increased during sales promotion period as a result consumer reacts immediately, since for consumers, who did not purchase such product before, will satisfy their needs and wants while the products' price is low (Pauwels, Hanssens, \& Siddarth, 2002).

Banks \& Moorthy (1999) who found that sales promotion led to sudden increase of sales experienced by retailers due to price-consciousness of consumers. Sinha \& Smith (2000), opinioned that consumer would be easily swayed to buy products as there is no extra cost by consumers. Blackwell, Miniard \& Engle (2001) identified that price discounts play a significant role in influencing consumer product trial behaviour which indirectly attracts new consumer. and prefer certain stores to others because of their attractive sales promo offers. Clow \& Baack (2007) stated that it is observed that 
the sales volumes of products are increasing during the sales promotion periods in many countries like United Stated of America, United Kingdom and Germany. Sales increase for three reasons. For certain current brand users will purchase their product in higher quantities for their future needs and wants; therefore, the consumption of the product is going to increase. Also it will help support product to its current consumers and become loyal to this brand. Consumers of competing brands may switch and purchase other branded products during its sales promotion because of the reduction in the product price. However, it is unknown that if these consumers will repeat their purchases again from their original brand or not. Consumers, who did not purchase such product before, may be attracted to purchase this product since its value is very high; hence the consumer is buying this product his/her needs and wants will be satisfied with minimum cost and risk.

Also sales promotions are playing an important role in consumer perception. According to self-perception theory stated that consumers mainly prefer to purchase products based on external attributes, which is taking advantage of price reduction, instead of internal attributes, which is brand preferences. However, the main weakness point of sales promotion in influencing consumer buying behaviour is that according to price perception theory, consumers mainly build a reference based on the previous prices of the product. Then this reference is used to compare between the current price of this product and pervious prices as well. Nagadeepal, Tamil \& Pushpa (2015) also found that pricing helps shape consumers' perception of a product. Using sales promotion is mainly increasing the degree of hesitation to buy a certain brand in its non-promotion period. As a result, it may increase sales for short term, but it influence negatively on brand equity in long term (Aggrawal \& Aggrawal, 2012; Pauwels, Hanssens, \& Siddarth 2002).

\section{Objectives and Use of Online Sales Promotion}

Sales promotions are used for varieties of reasons. Some of the objectives include introducing the new products to the consumers or induce to buy the new products for resale. Secondly, it is to attract the consumers or to increase the ultimate response from them. Thirdly, to induce the present consumers to repeat purchase more and maintain or increase the sales volume even during off seasons Online sales promotion also helps introduce new brand or the established brands to users and also increase the loyalty of the consumers. Lastly, it is to reward loyal customer. 
The importance of online sales promotion has increased with the increasing competition globally. The reason for increasing importance of the sales promotion is to have favorable sales and future expansion of the sales. It has become the part of the marketing strategy for the survival at any obstacles or with the new birth of products or brands. There is no doubt about the foundational findings in the literature- sales promotions are associated with major increases in consumer sales. The results can either be short or long term and could influence online store choice, brand choice, consumption rate and even new product trial behaviour of consumers (Gedenk \& Neslin, 1999).

The value of sales promotion from the consumers' perspective can be classified as utilitarian or hedonic benefits (Chandon, Wansink, \& Laurent, 2000; Liao, Toya, Lepak, \& Hong, 2009). Six significant benefits ought to be mentioned: financial savings, quality, convenience, value expression, exploration and entertainment. Acknowledging the value of the sales promotions from the consumer's point of view will help in understanding better their effectiveness. Price promotions are primarily related to utilitarian benefits (cost-saving,increased quality and convenience), which have an instrumental, functional and cognitive nature. Nonetheless, when they offer intrinsic stimulation, entertainment, fun and self-satisfaction, sales promotions are regarded as being hedonic.

\section{Perception of Online Shopping Sales Promo}

Consumer perception is formed by the online environment wherein information about the shop and products that are to be purchased, and the situation when shopping like searching for merchandise is at ease. This exposure greatly affects the consumer's purchase behaviour; who then decides if there would be a guaranteed satisfaction (Jun \& Jaafar, 2011). However, purchase behaviour is influenced by the consumer's perception of the quality and value of the service referred to as consumerist ethos by scholars (Stilwell, 2006). The way a consumer responds to certain online products is determined through his purchase behaviour like his product choice and even the brand choice. The worth of a product in the minds of the consumer is very much capable in predicting the purchase intentions of the products (Chen \& Dubinsky, 2003).

Shanthi \& Kannaiahs (2015) study reveals that perceptions toward online shopping and intention to shop online are not only affected by ease of use, usefulness, 
and enjoyment, but also by exogenous factors like consumer traits, situational factors, product characteristics, previous online shopping experiences, and trust in online shopping. Apart from these, some other scholars who found similar factors also included credibility and trust (Puranik \& Bansal, 2014; Thakur \& Aurora 2015; Makwana, Dattani, \& Badlani, n.d.; Ailawadi, Gedenk, Lutzky, \& Neslin, 2007). These major factors are therefore the determining factors of patronage of online shops among consumers globally.

\section{THEORETICAL FRAMEWORK}

This study is driven by Consumer Perception Theory which is a philosophical attempt to understand how consumers' perception of products and services influences their purchase behaviour. This theoretical process rests on the concept of sensory perception in marketing and advertising. This relates to how human beings perceive and process sensory stimuli through the five senses. Consumer perception also pertains to how people form opinions about companies and their products through purchase decisions. (LaMarco, 2018). Mainly, consumer perception theory attempts to explain consumer behaviour by analyzing motivations for their buying decisions and preferences.

Mathwick, Malhotra \& Rigdon (2001) say that if consumers enjoy their online shopping experience, they have a better attitude toward online shopping, and are likely to adopt the internet as a shopping medium. Likely, value perception is the part of the consumer perception theory that attempts to understand how consumers' perceptions of product influence their behaviour.

\section{RESEARCH METHOD}

The qualitative study gathered data through four sessions of focus group discussion (FGD) conducted among students of Fountain University to understand their perception of online shopping sales promo. The participants were selected using purposive and snowball sampling techniques. The purposive sampling involved only students that shared the same characteristics relating to this study which is shopping online. Then students that were selected through purposive sampling also iden- 
tified other students that had at least, once, shopped online. Focus group discussion is a good way to verify that peoples stated preferences are the same as their actual preferences. The FGD conducted made talking to the group of people reveal their actual preferences. Each sessions of the focus group discussion lasted for 90 minutes as it helped explore the discussion topic. It was conducted in a public place that was convenient for the participants and it was ensured that all participants were comfortable and engaged with the discussion, and that their opinions were being heard. An audio recorder was used and notes were taken during the FGD sessions. The audio files of the FGD sessions were transcribed into texts accordingly immediately the FGD sessions were completed. We first adopted corpus analysis, using voyant tools to present the data. This gave the data some form of quantification yielding graphical and numerical representation of the study results without suppressing the qualitative approach primarily adopted to report the lived experience of the sampled undergraduates about online sales promotions. Further, the data were discussed in qualitative method adopting theme building and textual explanation of the qualitative data obtained from FGD.

\section{DATA PRESENTATION AND ANALYSIS}

In the presentation and analysis of the data, the researchers adopted corpus analysis with the use of voyant tools (https://voyant-tools.org/?corpus=fa713bba99bce 2 bfaacb0bf1b98e05bb) to convert the qualitative data obtained from FGD to trend charts. The corpus analysis applied thematic links, dominant terms and frequency of occurrence among the themes of the corpus (textual data from FGD). Figures 2 and 3 graphically represent the corpus from the FGD data while the analysis of the trend and dominant themes follow. 


\section{Figure 2}

Respondents' Trust in Sales Promo by Online Stores

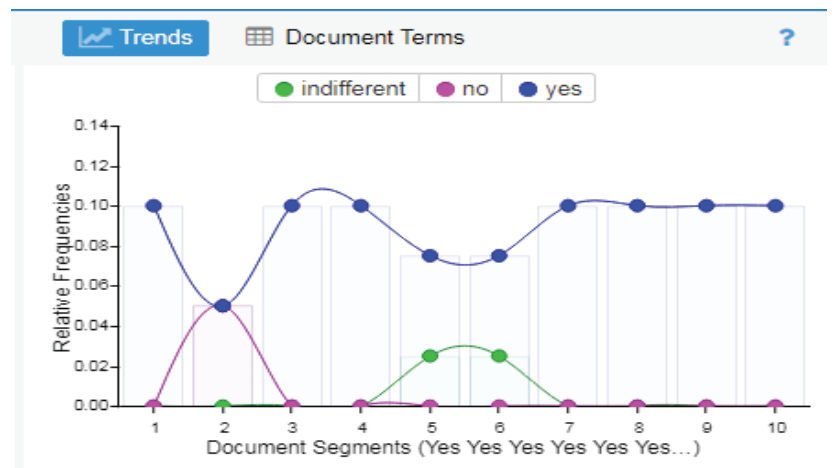

When the researchers asked the undergraduates who participated in FGD sessions if they trusted sales promo by online stores, all of them except a few responded in the affirmative. This is an indication that sales promo is highly significant to online purchase. It is also a valid premise to the inference that sales promo can increase online purchase significantly. The fact that majority trusted online sales promo sufficiently supports the conclusion that sales promo is a veritable marketing communication and promotional tool in online marketing of goods and services. Hence, the use of sales promo strategies like price reduction, add-on products, coupons, etc are complementary to boosting sales of commodities by online stores.

\section{Figure 3}

Respondents' Reason for Shopping Online

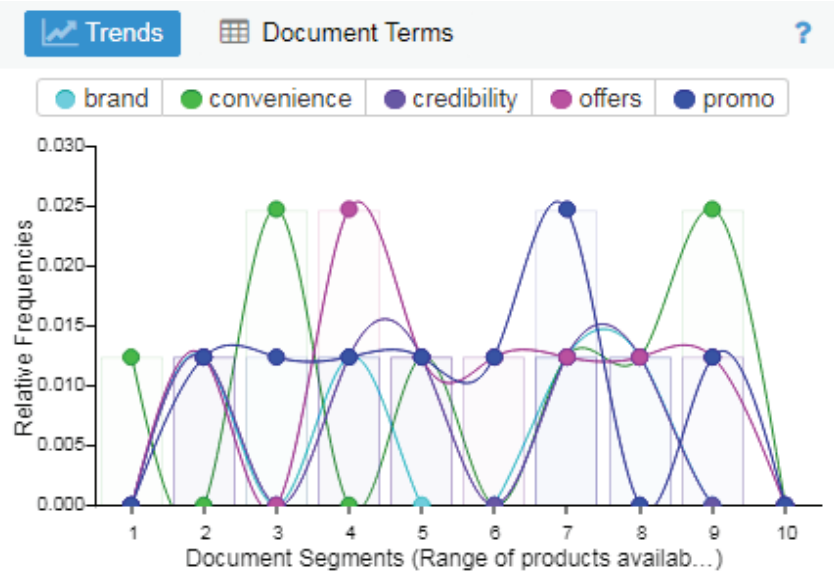


Because human beings usually act on reasons; they hardly take decisions baselessly. Most observed behavioural patterns in human beings are reasoned-behaviour. Buying and consumption have also been regarded as habits or behaviour. This supports the study of consumer behaviour in marketing profession. When a consumer buys a commodity or requests for a paid-service, they do so based on reason(s). As part of the data collection process, the researchers asked the FGD participants to mention reasons behind their online buying behaviour. To ensure engagement with extant literature and reduce responses to manageable number of regular responses, a checklist containing twelve (12) conceptual and empirical reasons extracted from relevant literature was presented to respondents to choose from. These include range of products available, convenience, customer service, high quality of product, delivery service, brand credibility, promo offers, price tags and accessibility, reliability, quality of product, price range and wide range of products.

Using voyant tool for analysis, the responses of the FGD participants were imported as corpus yielding a vocabulary density of 0.272 . This is a reliable representation of significant relationship in the respondents' thought flow. The corpus analysis indicated the most frequent words as follows: convenience (8); offer (8); promo (8); credibility (5) brand (4). This implies that the greatest reasons why undergraduates shop online were convenience, available offer and sales promo. The credibility of the online store and its brand integrity are also strong reason for online purchase among our respondents. All these unique words have direct relationship with the range of products available. Meaning that those leading factors are drivers to motivate online buyers to visit the site of an online store but range of products available plays significant role in the buying decision by online buyers as represented in the opinions and experience of the undergraduates under study.

\section{DISCUSSION OF FINDINGS}

This section contains the presentation and discussion of data collected through focus group discussion. The data were presented in form of textual analysis and therefore segmented based on themes derived from the guiding questions that drive the study.

The findings of this study are categorized into five themes which are perception, preference, pricing and negotiation, factors determining patronage, online and offline sales promo. They are therefore presented in the following sections. 


\section{Perception}

Major findings of students' perception about online sales promo revealed that a good number of students in Fountain University trusts online sales promo and they perceive it as something that is good because they have benefitted well from it and it has enhanced their online buying behaviour.

Figure 2 (see data analysis section) shows the respondents' perception about online sales promo indicating significant trust for online sales promo. But Figure 3 shows the participants responses on reasons they shop online. The tables point out the responses of the participants across the four sessions of the focus group discussion. As obtained from the data most of these students trust online sales promo and it influences their shopping habits as it makes them want to buy more than they intended to. This fact is supported by Banks \& Moorthy (1999) who found that sales promotion led to sudden increase of sales experienced by retailers due to price-consciousness of consumers. Sinha \& Smith (2000), opinioned that consumer would be easily swayed to buy products as there is no extra cost by consumers. Blackwell et al. (2001) identified that price discounts play a significant role in influencing consumer product trial behaviour which indirectly attracts new consumer. and prefer certain stores to others because of their attractive sales promo offers. There are students that ordinarily preferred shopping for products at the regular prices than getting a counterfeit or less quality at reduced or low price. Where they are sure of quality product, sales promo is a significant sales driver. In fact, recent studies affirm this finding that sales promo leads to impulse purchase even when the buyer may regret the having purchased an unneeded product thereafter (Jiang \& Ma, 2018; Kempa, Vebrian \& Bendjeroua, 2020).

\section{Pricing and Negotiation}

It was discovered that pricing and negotiating also affect the shopping behaviour of students under this study. According to scholars like Aggrawal \& Aggrawal, 2012 and Nagadeepa1, Tamil \& Pushpa (2015), product pricing as a sale promotion technique has an impact on deriving consumer perception and the extent to which perception is influenced, is derived from nature of consumer behaviour. Online buying reduces the power of negotiation of consumers as it robs them of the power to negotiate. 


\section{Online Shopping Sales Promo and its Perception Among Undergraduate Students in Osogbo, South Western Nigeria}

The students revealed that pricing and negotiating made them bad price negotiators when shopping from offline stores, that is why they do regular patronage of online stores and it was also discovered that it makes them look for better stores elsewhere that will agree to their price negotiation. A participant said online shopping is more expensive and she knows they have fixed prices and that is why she also has particular products she buys online. They already know all that comes with shopping online which is mostly getting fixed prices to their products. There were some that preferred shopping for only products they cannot be easily gotten elsewhere from online stores and shop for other products from offline stores where they can easily negotiate and gives them the zeal to always want to patronise certain online stores more. Pricing affects the decision to use the internet to purchase goods and services since most customers expect the online prices to be lower than physical store prices. According to research, this is because the customers assume that the online stores have lower overhead costs compared to physical stores. Studies also show that customers only compare prices with physical stores and do not make comparisons between online stores offering the same products or services. Online shopping has really reduced the power of pricing and negotiation of consumers as it is expected for them to get products without attempts to negotiate as there are fixed prices. There are only exceptional cases of few online stores that make room for negotiation.

\section{Preference}

Data obtained from the FGD also revealed that students preferred certain online to others due to certain reasons which include range of products, reliability, quality of products, delivery service, customer service, promo offers, price tags and accessibility, quality of products, convenience, and credibility. This fact is supported by Ernst \& Young (2001) who reported that Internet users purchased online because of good product selection, competitive prices, and ease of use. Alka \& Tandon (2014) made study using questionnaire with 200 customers as a sample. The study revealed that customers are very satisfied towards online shopping because of the delivery system is working effectively therefore customers are doing shopping again and again but there were cases of some online stores having poor delivery service which them create a perception about those online stores. The optimal design, format, and timing for online shopping sales promotion is influenced by a wide variety of factors. These 
include internal consumer factors such as brand preferences and variety seeking behaviour (Zhang \& Krishnamurthi, 2004). Therefore, it is important to adjust sales promotion by tracking each customer's unique promotion sensitivity and response tendencies over time.

\section{Online and Offline Sales Promo}

Findings gotten from the FGD conducted builds the fact that students preferred products with online sales promo offers as it influences them to do impulse buying and do products trial. Students even wait for certain occasions to enjoy sales promo, occasions like Easter sales promo or 50\% off sales, Jumia Black Friday, Jumia Treasure Hunt, Ramadan promo/giveaway, Lucky Tuesday and other festival promos.

The researcher has discovered from the data obtained that students would not mind waiting for occasions to shop for products solely due to sales promo and sales promo has convinced a number of them to try new products. Since a number of them are attracted to online sales promo, it helps online retailers gain more customers to their stores. It was discovered that students see Jumia, Konga, Ali express, Amazon, and some notable Instagram stores as online stores that are reliable and best in terms of standard and quality of products.

\section{Factors Determining Patronage}

Data obtained from this research also revealed that there are some factors that determine patronage of online stores. As much as online shopping seems good to the students, they did not hide the fact that they also get scammed online by fake online stores which has made some of them not to make regular patronage with online stores except it is based on recommendation from someone they trust. Our corpus analysis of the FGD response text shows that trust is the most significant factor in online sales promo (see table 1 above). Besides this, convenience, offers, promo and brand credibility are positively significant to patronage of online stores by the undergraduates in this study.

The students through the FGD conducted made mention that online sales promo has done better than offline sales because they make more awareness and they clearly 
state their terms and conditions of enjoying the sales promo offers. If offline stores, make their sales promo offers known to the consumers using the internet to promote it then online stores will be at the detriment even though there are still variant advantages of shopping online and they do more of sales promo offers. This is consistent with the findings of Tarigan, Sabrina \& Syahputri (2020), Jiang \& Ma (2018), Chang (2017) and Gao (2015).

Basically, all the findings of this study proves right the assumptions of the consumer perception theory. This is on the basis that our respondents said their trust in the genuineness of online sales promo and brand credibility are among the strong factors determining their buying decision online. This is the psychological process of opinion moulding involved in purchase decision and buying behaviour as explained by LaMarco (2018) and Mathwick et al. (2001) in their consumer perception theory hypothesis.

\section{CONCLUSION AND RECOMMENDATIONS}

Every research carried out has a purpose, and that purpose at the end helps in identifying and solving problems. This research set out to know the perception of Nigerian undergraduates towards online shopping sales promo using Fountain University students as a case. In the course of this research, it was identified that online shops should do more to ensure they gain full trust of their customers and not have students having doubts about purchasing products that are on sales promo. Online stores having attractive sales promo offers, good recommendation from customers, and comes with good delivery service, customer service, reliable will only endear more customers to the stores.

Following the findings of the study, it was concluded even though the students enjoy online sales promo, they still get skeptical for some products as they do not want to end up with fake products. All these boils down to the fact that online shopping sales promo has lots of offers on every product gotten and this makes the students want to keep patronising online stores, online stores should also make sure they are giving out the best value for every product this will make even students that do not trust online sales promo see reason to get products as they know they will get the valued gifts and discounts. 
Based on the findings of the study, it was discovered that online sales promo greatly influences students online buying behaviour as it makes them do impulse buying and try out new products. The scams online prevent some students from shopping online or even trusting products on sales promo and fixed prices from online stores also makes some students lose interest in shopping online. It is then recommended that online stores should make sure their products are of high quality so that consumers would have good perception about their brand and there should be room for negotiation on regular products that can be gotten elsewhere.

The study also recommends that they should have an effective delivery system because respondents reported several cases of late delivery from the side of the online stores. Also, if the online sellers want to grow they have to provide more convenience, competitive price, more variety, after sales services in order to attract more people to make an online purchase decision.

\section{REFERENCES}

Adeyeye (2008). E-commerce, business methods and evaluation of payment method in Nigeria. Electronic Journal of Information Systems Evaluation, 11 (1).

Aggrawal, S., \& Aggrawal, A. (2012). A critical analysis of impact of pricing on consumer buying behaviour in apparel retail sector: a study of mumbai city. International Journal of Multidisciplinary Educational Research, 1(1), 34-44. Retrieved August 15, 2019 from http://ijmer.in/pdf/volume1-issue1-2012/34-44. pdf

Ailawadi, K. L, Gedenk, K., Lutzky, C., \& Neslin, S. A. (2007). Decomposition of the sales impact of promotion-induced stockpiling. Journal of Marketing Research, 44(3), 450-467. Retrieved on September 26, 2019 from https://www.jstor.org/ stable/30162492

Al-Debei, M., Akroush, M., \& Ashouri, M. (2015). Consumer attitudes towards online shopping: The effects of trust, perceived benefits, and perceived web quality. Internet Research, 25(5), 707-733. 
Online Shopping Sales Promo and its Perception Among

Undergraduate Students in Osogbo, South Western Nigeria

Alka, K., \& Tandon, J. K. (2014). Factors Influencing Customer's Satisfaction Level Towards Online Shopping in Jaipur and Gurgaon. International Journal of Innovative Research and Development, 3(4), 348-356.

Amankwah, A. B. \& Asare, G. (2019). The impact of sales promotional packages on customer switch and retention: case of MTN and Vodafone Ghana Ltd. International Journal of Academic Research and Reflection, 7 (4), 26-41.

Andreti, J., Zhafira, N. H., Akmal, S. S., \& Kumar, S. (2013). The analysis of product, price, place,promotion and service quality on customers' buying decision of convenience store: a survey of young adult in Bekasi, West Java, Indonesia. International Journal of Advances in Management and Economics, 2(6), 72-78. Retrieved August 28, 2019 from https://www.researchgate.net/ publication/323308768_The_Analysis_of_Product_Price_Place_Promotion_ and_Service_Quality_on_Customers\%27_Buying_Decision_of_Convenience_ Store_A_Survey_of_Young_Adult_in_Bekasi_West_Java_Indonesia

Banks, J., \& Moorthy, S. (1999). A Model of Price Promotion. International Journal of Industrial Organization, 17, 371-398.

Blackwell, R.D., Miniard, P. W., \& Engel, J.F. (2001). Consumer Behaviour, 9th ed. Fort Worth. TX: Harcourt College Publishers.

Busse, K. (2009). Fans, Fandom, and Fan Studies. In S. W. Littlejohn \& K. A. Foss (Eds.). Encyclopedia of Communication Theories (pp. 386-390). London: SAGE Publications, Inc.

Chandon, P., Wansink, B., \& Laurent, G. (2000). A benefit congruency framework of sales promotion effectiveness. Journal of Marketing, 64(4), 65-82. Retrieved June 14, 2019 from https://www.researchgate.net/publication/233777673_A_ Benefit_Congruency_Framework_of_Sales_Promotion_Effectiveness

Chang, A. Y.-P. (2017). A Study on the Effects of Sales Promotion on Consumer Involvement and Purchase Intention in Tourism Industry. EURASIA J MATH SCI T, 13(12). https://doi.org/10.12973/ejmste/77903 
Chen, Z., \& Dubinsky, A. J. (2003). A conceptual model of perceived customer value in e-commerce: a preliminary investigation. Journal of Psychology and Marketing, 20(4): 323 - 347. Retrieved September 18, 2019 from https://onlinelibrary.wiley. com/doi/abs/10.1002/mar.10076

Clow, K. E., \& Baack, D. (2007). Integrated advertising, promotion and marketing communication, 4th Edition. Pittsburg State University.

eMarketer. (2016). Worldwide retail ecommerce sales will reach $\$ 1.915$ trillion this year. Retrieved May 14, 2018, from https://www.emarketer.com/Article/WorldwideRetail-Ecommerce-Sales-Will-Reach-1915-Trillion-This-Year/1014369

eMarketer. (2018). Retail ecommerce performance metrics. Retrieved May 14, 2018, from https://www.emarketer.com/performance

Ernst \& Young LLP. (2001). Global online retailing. New York: Ernst and Young LLP. Forrester Research, Inc. Retrieved May 10, 2019 from http://www.forrester.com

Folorunso, O., Awe, O. G., Sharma, S. K., \& Zhang, J. (2006). Factors affecting the adoption of e-commerce: a study in Nigeria. Journal of Applied Sciences, 6, 22242230. Retrieved on September 26, 2019 from https://scialert.net/abstract/?doi= jas.2006.2224.2230

Gao, L. (2015). Understanding consumer online shopping behaviour from the perspective of transaction costs. [PhD thesis]. University of Tasmania. https:// eprints.utas.edu.au/22877/

Gedenk, K., \& Neslin, S. A. (1999). The role of retail promotion in determining future brand loyalty: its effect on purchase event feedback. Journal of Retailing, 75(4), 433 - 459. retrieved May 20, 2019 from https://www.sciencedirect.com/science/ article/abs/pii/S0022435999000184

Hajli, N. (2014). A study of the impact of social media on consumers. International Journal of Market Research, 56(3), 387-404.

Hoque, M., Ali, M., \& Mahfuz, M. (2015). An Empirical Investigation on the Adoption of E-Commerce in Bangladesh. The Asia Pacific Journal of Anthropology, vol. 25, 1-24. https://doi.org/10.14329/apjis.2015.25.1.001 
Online Shopping Sales Promo and its Perception Among

Undergraduate Students in Osogbo, South Western Nigeria

Jiang, H., \& Ma, J. (2018). Effects of Internet Sales Promotion on a Differential Advertising Model. Discrete Dynamics in Nature and Society, 2018, 1-11. https:// doi.org/10.1155/2018/8618146

John, S. (2018). E-commerce trends + facts. Retrieved May 14, 2018, from https:// endertech.com/blog/e-commerce-trends-facts

Jun, G., \& Jaafar, Noor. I. (2011). A study on consumers' attitude towards online shopping in china. International Journal of Business and Social Sciences, 2(22), 122-132. Retrieved May 10, 2019 from http://www.ijbssnet.com/journals/ Vol_2_No_22_December_2011/15.pdf

Katawetawaraks, C., \& Wang, C. (2011). Online shopper behavior: Influences of online shopping decision. Asian Journal of Business Research, 1(2). https://ssrn. com/abstract $=2345198$

Kempa, S., Vebrian, K., \& Bendjeroua, H. (2020). Sales Promotion, Hedonic Shopping Value, and Impulse Buying on Online Consumer Websites. SHS Web Conf., 76, 01052. https://doi.org/10.1051/shsconf/20207601052

Kotler, P., \& Keller, K. (2014) Marketing management. 15th Edition. Saddle River: Prentice Hall.

Kumawat, A., \& Tandon, J. K.. (2014). Factors influencing customer's satisfaction level towards online shopping in Jaipur and Gurgaon. International Journal of Innovative Research and Development, 3(4), 348-356. Retrieved July 5, 2019 from http://www.internationaljournalcorner.com/index.php/ijird_ojs/article/ view/134741

LaMarco, N. (2018). Consumer perception Theory. Small Business - Chron.com. Retrieved July 10, 2019 from http://smallbusiness.chron.com/consumerperception-theory-40176.html

Liao, H., Toya, K, Lepak, D. P., \& Hong, Y. (2009). Do they see eye to eye? management and employee perspectives of high-performance work systems and influence processes on service quality. The Journal of Applied Psychology 94(2), 371-91. Retrieved July 8,2019 from https://www.researchgate.net/publication/24187175_ Do_They_See_Eye_to_Eye_Management_and_Employee_Perspectives_of_ High-Performance_Work_Systems_and_Influence_Processes_on_Service_ Quality 
Liu, X., He, M., Gao, F. \& Xie, P. (2008). An empirical study of online shopping customer satisfaction in China: A holistic perspective. International Journal of Retail Distribution Management, 36(11), 919-940.

Makwana, K., Dattani, K., \& Badlani, H. (n.d.). A customer perception towards online shopping: an exploratory study. Altius Shodh Journal of Management \& Commerce. Retrieved September 26, 2019 from https://pdfs. semanticscholar.org/a1aa/e288f09535c58fd84c3fe11418cf830d6b07.pdf? $\mathrm{ga}=2.20647292 .516307671 .1581669350-1546531357.1569508321$

Mathwick, C., Malhotra, N., \& Rigdon, E. (2001). Experiential value: conceptualization, measurement and application in the catalog and Internet shopping environment. Journal of Retailing 77(1), 39-56. Retrieved August 15, 2019 from https://www. sciencedirect.com/science/article/abs/pii/S0022435900000452

Mudambi, S., \& Schuff, D. (2010). What Makes a Helpful Online Review? A Study of Customer Reviews on Amazon.com. MIS Quarterly, 34(5), 185-200.

Nagadeepal, C., Tamil, S. J., \& Pushpa, A. (2015). Impact of Sale Promotion Techniques on Consumers' Impulse Buying Behaviour towards Apparels at Bangalore. Asian Journal of Management Sciences \& Education, 4(1), 116-124. Retrieved December 8, 2020 from http://www.ajmse.leena-luna.co.jp

Nakarmi, A. (2018). Effect of Sales Promotion on Consumer Behaviour. A Bachelor Thesis of Seinäjoki University of Applied Sciences. 1-44. Retrieved July 14, 2019 from https://www.theseus.fi/bitstream/handle/10024/142006/anuraj\%20 thesis\%20final.pdf?sequence $=1$ \&isAllowed $=y$

Nebojsa, V., Milorad, K., \& Tanja, K. (2019). The Influence of Online Shopping Determinants on Customer Satisfaction. Journal of Theoretical and Applied Electronic Commerce Research, 14(2).

Novak, T., Hoffman, D., \& Yung, Y. (2000). Measuring the Customer Experience in Online Environments: A Structural Modeling Approach. Marketing Science,19(1), 22-42.

Pauwels K., Hanssens D. M., \& Siddarth S. (2002). The long-term effects of price promotion on category incidence, brand choice, and purchase quantity. Journal of Marketing Research, 39(4), 421-439. Retrieved May 10, 2019 from https:// www.jstor.org/stable/1558555?seq=1 
Online Shopping Sales Promo and its Perception Among

Undergraduate Students in Osogbo, South Western Nigeria

Philips Consulting Ltd. (2016). The 2016 online shopping survey. Retrieved on September 24, 2019 from https://phillipsconsulting.net/reports_post/the-2016online-shopping-surv/

Puranik, R., \& Bansal, A. (2014). A study of internet users' perception towards e-shopping. Pacific Business Review International, 6(9), 37-44. Retrieved on September, 26, 2019 from http://www.pbr.co.in

Schrøder, K. C. (2009). Audience Reception Theories. In S. W. Littlejohn \& K. A. Foss (Eds.), Encyclopedia of communication theories (pp. 386-390). London: SAGE Publications, Inc.

Sinha, I., \& Smith, M. F. (2000). Consumers' perceptions of promotional framing of price. Psychology \& Marketing, 17(3), 257-275. Retrieved September 10, 2019 from https://doi.org/10.1002/(SICI)1520-6793(200003)17:3\%3C257::AIDMAR4\%3E3.0.CO;2-P

Shamout, M. D. (2016). The impact of promotional tools on consumer buying behaviour in retail market. International Journal of Business and Social Science, 7(1), 75-85. Retrieved May 10, 2019 from https://ijbssnet.com/journals/Vol_7_ No_1_January_2016/9.pdf

Shanthi, R., \& Kannaiah, D. (2015) Consumers' perception on online shopping. Journal of Marketing and Consumer Research, 13, 14-20. Retrieved June 20, 2019 from https://researchonline.jcu.edu.au/39753/1/Dr.\%20Desti\%20Consumers\%20 perception\%20on\%20Online\%20Shopping.pdf

Shergil, G., \& Chen, Z. (2005). Web-based shopping: Consumers' attitudes towards online shopping in New Zealand. Journal of Electronic Commerce Research, 6(2).

Sorce, P., Perotti, V., \& Widrick, S. (2005). Attitude and age differences in online buying. International Journal of Retail and Distribution Management, 33(2):122132. 
Stilwell, C. (2006). "Boundless opportunities?": towards an assessment of the usefulness of the concept of social exclusion for the South African public library situation. Innovation, 32. Retrieved on September 26, 2019 from https://www. researchgate.net/publication/228864541_Boundless_opportunities_towards_ an_assessment_of_the_usefulness_of_the_concept_of_social_exclusion_for_ the_South_African_public_library_situation

Strauss, J., \& Frost, R. (2012). E-Marketing. São Paulo:Pearson Prentice Hall.

Tarigan, E. D. S., Sabrina, H., \& Syahputri, Y. (2020). The Influence of Lifestyle and Sales Promotion on Online Purchase Decisions for Home-Cooked Culinary during COVID-19 in Medan City, Indonesia. International Journal of Research and Review 7(10), 140-144. https://www.ijrrjournal.com/IJRR_Vol.7_Issue.10_ Oct2020/Abstract_IJRR0020.html

Thakur, S., \& Aurora, R. (2015). Consumer perception: a study on e-marketing. International Journal of Recent Research Aspects, 2(2), 256-262. Retrieved on September 26, 2019 from http://ijrra.net/Vol2issue2/IJRRA-02-02-50.pdf

Voyant Tools.org (2020). Voyant Tools. Accessed on December 3, 2020 from https:// voyant-tools.org/?corpus $=\mathrm{d} 75 \mathrm{c} 9 \mathrm{ee} 427 \mathrm{db} 1 \mathrm{e} 9 \mathrm{e} 5 \mathrm{c} 2 \mathrm{bcfcb} 38 \mathrm{~b} 386 \mathrm{~b} 9$

Zhang, J., \& Krishnamurthi, L. (2004). Customizing promotions in online stores. Marketing Science. 23 (4). 561-578. Retrieved August 5, 2019 from https:// www.researchgate.net/publication/227442350_Customizing_Promotions_in_ Online_Stores

Zuroni, J., \& Goh, L. (2012). Factors Influencing Consumers' Attitude Towards E-commerce Purchases Through Online Shopping. International Journal of Humanities and Social Science, 2(4). 